\title{
Structural Design of Blocking Element of Magnetic Cycloid Transmission
}

Juraj Bezák ${ }^{1}$, Peter Bezák ${ }^{1}$, Alena Vajdová ${ }^{2}$

${ }^{1}$ Department of Design and Mechanical Elements, University of Žilina, Univerzitná 8215/1, 01026 Žilina, Slovak Republic. E-mail: juraj.bezak@fstroj.uniza.sk, peter.bezak@fstroj.uniza.sk

${ }^{2}$ Faculty of Mechanical Engineering, University of Žilina, Univerzitná 8215/1, 01026 Žilina, Slovak Republic.

E-mail: alena.vajdova@fstroj.uniza.sk

The contribution deals with the study of magnetic structures, computational methods used in analyzing the interaction of magnetic fields with application this knowledge in practice.

The main object of study is design of blocking element of magnetic cycloid gearbox. This paper describes the design methodology of magnetic blocking element, calculation of the braking system, the maximum breakaway torque at slipping in magnetic coupling and power ratios during this action.

Keywords: blocking element, stress analysis, visualization

\section{Acknowledgement}

This work was supported by the Scientific Grant Agency VEGA of the Ministry of Education. Reg. Project number: 1/0881/11, project title: Research of magnetic bond of gear assembly.

\section{References}

[1] FURLANI, E. (2001). Permanent magnet and electromechanical device. San Diego, CA: Academic Press, 500 s. ISBN 0-12-269951-3

[2] MORALES, W. - FUSARO R. (2003). Permanent magnetic bearing for spacecraft aplications. [online]. Dostupné na internete: <http://gltrs.grc.nasa.gov/reports/2008/TM-2003-211996-REV1.pdf >. NASA/TM-2003211996/REV1

[3] BEZÁK, J. (2011). Vývoj bezkontaktných prevodových systémov na báze interakcií magnetických polí: Diplomová práca. Žilina : Žilinská univerzita. $75 \mathrm{~s}$.

[4] Ansys Inc. (2007). Release 11.0 Dokumentation for Ansys. Elektronický manuál k aplikácii Ansys.

[5] HATCH, G. (2010). Recent developments in permanent magnet gear systems and machines. [online]. Dostupné na internete: $<$ http://www.terramagnetica.com/papers/hatch-permanent-magnet-gears.pdf $>$.

[6] MÁLIK, L. a kol. (2003). Časti a mechanizmy strojov. Žilina : EDIS, 535 s. ISBN 80-8070-043-5.

[7] VAJDOVA, A., a kol. (2014). Analysis of Surface Integrity of Parts after Non-conventional Methods of Machining. Manufacturing Technology, Vol. 14, No. 3

[8] JAKUBOVIČOVÁ, L., SÁGA, M., VAŠKO, M. (2013). Impact Analysis of Mutual Rotation of Roller Bearing Rings on the Process of Contact Stresses in Rolling Elements. In: Manufacturing Technology Vol. 13, No.1 